\title{
The impact of culture and relational quality in the cooperation between export companies and local distributors
}

\author{
Gisela Alves* \\ Marketing Department, \\ IPAM Porto (European University, Laureate International Universities, \\ CECS, University of Minho. \\ Portugal \\ Email: giselamariamaiaalves@gmail.com
}

*Corresponding author

Received Feb, 2018; Accepted May, 2018

\begin{abstract}
The increased globalization and internationalization of business has highlighted the importance of understanding the role of culture and the quality of relations in influencing the cooperation between companies from a cross-cultural perspective. The role of trust and commitment, on one side, and the role of cultural similarities and dissimilarities, on the other hand, was sparsely examined in international contexts. Thus, the aim of this research is to understand how the culture and the quality of relations characterized by trust and commitment affect the established cooperation between Portuguese exporting companies and their distributors in Angola. For this purpose, a qualitative analysis is carried out in five Portuguese exporting companies and five Angolan distributors. The selection of Portuguese companies was based on a list of the largest fifty Portuguese exporting companies to Angola, based on the Portuguese Investment and Foreign Trade Agency, EPE (AICEP), in August 2011. After conducting interviews with the managers of exporting companies, the collaborators responsible for the export activities, and the Angolan distributors, the results show that culture, trust and commitment have an impact on the cooperation between Portuguese exporting companies and their Angolan distributors.
\end{abstract}

Keywords: Angola; Portugal; Exporter; Distributor; Relationship Marketing; International Marketing; Culture; Trust; Commitment and Cooperation.

Type: Research paper

This work is licensed under a Creative Commons Attribution 4.0 International License.

\section{DOI: 10.51325/ijbeg.v1i2.13}

\section{Introduction}

This research approaches culture focusing on how Portuguese and Angolan cultural dimensions are interconnected with some dimensions of relationship marketing in a context of international trade.

Despite the existence of extensive literature on trust and commitment, there is a gap in the study of these constructs in the international context, which does not refer an exporterside study. As referred by Saleh et al. (2014), although there is an absolute number of models of determinants and consequences of trust and a commitment to consolidation, a review of the literature reveals that the international context of trust and the commitment 
of industrial distributors have not been explored in a sustained manner. Also, Kim, Hibbard \& Swain (2011) note that they are more useful for a better understanding of how a distributor's commitment is generated.

This research is of great relevance in that the literature review allowed to identify, in terms of studies conducted so far, the existence of a gap regarding the analysis involving both sides of the commercial relationship. According to Lages, Lancastre \& Lages, (2008, p.694), "Another limitation actually results from the fact that the search depends only on buyers' responses. Ideally, authors should collect data from both sides of the dyad. However, as relationship marketing research is still at an early stage of development, we begin from a buyer's point of view ..." Actually, research has just focused on one side the exporter-distributor.

While international business literature shows numerous studies on the exporter's commitment, knowledge is very restricted with regard to a distributor's commitment behavior in a dyad. For example, Uppsala researchers focused on knowledge of the exporting firm and increased their commitment to the external market, forgetting the other side of the dyad (Karlsen et al., 2003; Alareeni, 2011; Alareeni, 2018). Understanding the international trade process, especially the engagement process, is crucial for managers to create and maintain successful relationships (Leonian et al, 2011). "In fact, distributors and exporters are usually linked by a networked relationship, extending across industrial and international borders, which is an understanding of both parties to build and maintain relationships" (Saleh, Ali \& Andaleeb, 2014, p.46).

In addition, studies on emerging markets are scarce. As mentioned by Saleh, Ali \& Andaleeb (2014, p.46) "... the context of developing / emerging countries has been largely ignored in studies of commitment in buyer-seller relationships, which limits the generalization of earlier findings. It is important to fill this gap in the literature because developing countries represent a different transaction context, subject to various resource constraints and fiscal management, as well as infrastructural, governance and related factors." Indeed, the literature review indicates that relationship marketing knowledge is based primarily on studies conducted in the US or Western contexts (Ha, Karande \& Singhapakdi, 2004) and that there have been relatively few studies focusing on the context of the exporter-distributor relationships.

As Griffith et al. (2006, p. 2) referred "... most the international business research on relationship resources (i.e., trust and commitment) and knowledge consists of singlecountry studies conducted in the United States, thus, providing researchers and practitioners little understanding of how firms from different national cultures perceive the associations between relationship and knowledge resources when operating intercultural relations. The lack of research on relationship resources ... from other cultural perspectives greatly limits the knowledge about these important resources of the company.

Another gap shown by the literature review is the impact of national cultures on business relationships. As Ha, Karande \& Singhapakdi (2004) state, the impact of cultural similarities/differences on relationship structures has not yet been adequately researched. 
These authors argue that the existence of differences between distributors' relational structures should be explored when the exporters concerned are of a similar culture as opposed to a different one. These differences are expected because of the perceived advantages of dealing with culturally similar exporters because of reduced cultural distance and behavioral transparency.

Also, Griffith et al. (2006) argue that, while relational resources (i.e. trust and commitment) have been the subject of much academic study, researchers still have to understand the impact of national culture on these key resources, which is a significant constraint given the impact that national culture has shown on various aspects of business. The same authors also point out that the increasing globalization of business has increased the importance of understanding the impact of national cultures on inter-organizational relationships.

The present investigation, when addressing the two sides of the exporter-distributor relationship, intends to contribute to the fulfillment of the literature gap regarding the analysis of both sides of the commercial liaison. When dealing with relationships of trust and commitment in an international context, it also aims to contribute to the fulfillment of the research gap that exists. Third, if the context of developing/emerging countries has been largely ignored in studies of commitment in buyer-seller relationships, the present study, in analyzing distribution companies in a developing African country, intends to contribute to the gap in the literature.

Finally, as the literature reveals, if the impact of cultural similarities/differences on the quality of relations has not been properly explored, the present study, when studying the impact of the national culture on the quality of relations, contributes decisively to filling in this gap.

In terms of methodology we opted for a qualitative analysis: five case studies of Portuguese exporting companies and five case studies of Angolan distributors were analyzed. Interviews with the managers / CEOs of the Portuguese exporting companies and the employees in charge of exporting activities were performed, as well as their corresponding Angolan distributors, to obtain answers to the research questions. The selection of the Portuguese companies was based on the list of the fifty largest Portuguese companies exporting to Angola provided by the Agency for Investment and External Commerce of Portugal, EPE (AICEP) in August 2011.

\section{Literature review}

Increasing liberalization, integration, and competition in the economic world since the post-war period have been responsible for the increasing growth of firms' export activities (Douglas \& Craig, 1995) because exports play a vital role in the world's economic agenda and it is expected that its importance will grow more as markets become more globalized.

Speaking about exports, when a company decides to introduce a product into an external market, a difficult issue must be resolved. Should the new product be distributed through 
a distribution channel owned by the company, or is it more efficient to hire an independent organization? Anderson \& Coughlan (1987) believe that, for an economist, this is a question of vertical integration, where the choice is between mainly captive agents (company sales force and distribution company division) or primarily independent distributors (sales agents and outside distributors). "To reduce risk when entering foreign markets, most exporters start collaborating with importers." (Miocevic, D., 2016 p.196).

Exports provide the traditional means of access foreign markets (Navarro-Garcia, Arenas-Gaitán \& Rondán, 2014). "When people started to exchange goods and services they also started to interact in relationships" (Gummesson, E., 2017, p.4).

\section{Relationship Marketing}

"Relationship Marketing: Strategic management of relationships with all relevant stakeholders. These include not only customers, but also suppliers, influencers, referral sources, internal markets, etc." (Raciti, M., \& Dagger, T., 2017, p. 3). "For a long time, relationship marketing was relying on the thinking that relationships always include a winwin situation" (Gummerus, J., Koskull, C. \& Kowalkowski, C., 2017, p.7). Relationship marketing aims to generate profitable, long-term relationships between partners (MiquelRomero, Caplliure-Giner \& Adame-Sánchez, 2014).

In 2004 the American Marketing Association (AMA) changed its definition of marketing that until then was "marketing is the process of planning and executing the conception, price, promotion and distribution of ideas, goods and services with a view of creating exchanges that meet individual and organizational goals " by another definition where marketing is a function of the organization and a set of processes to create, communicate and deliver value to customers and to manage customer relationships in a way that benefits the organization and the parties concerned.

According to Brito \& Lencastre, 2014, relationship marketing manages relationships and its goals are to retain customers, to monetize them and create a portfolio of clients, while transactional marketing manages resources and targets sales, product profitability and market share.

Gupta \& Sahu (2012, p.63) argue that an "effective relationship marketing program delivers better results in terms of increasing customer base, sales, and profitability." Marketing literature refers some important dimensions of relationship marketing, such as commitment, trust, cooperation, among others, factors that are very important for any business to consider in their marketing program (Gupta \& Sahu 2012). For MiquelRomero et al. (2014) satisfaction, trust, and commitment are the results of relationship marketing implementation.

Then, according to Gupta \& Sahu (2012, p.61-63), some of the dimensions of relationship marketing that will be analyzed in this investigation are presented. 
Table 1- Dimensions of Relationship Marketing

\begin{tabular}{|l|l|l|}
\hline Author (s) & Dimension & Definition \\
\hline $\begin{array}{l}\text { Moorman et al. } \\
\text { (1993); Orth \& } \\
\text { Green (2009) }\end{array}$ & Trust & $\begin{array}{l}\text { The willingness to count on an exchange partner in } \\
\text { whom one has trust. }\end{array}$ \\
\hline Gounaris (2005) & Commitment & $\begin{array}{l}\text { The desire for continuity manifested by the } \\
\text { willingness to invest resources in relationship. }\end{array}$ \\
\hline $\begin{array}{l}\text { Anderson \& \& } \\
\text { Lages et al. } \\
(2008)\end{array}$ & Cooperation & $\begin{array}{l}\text { Coordinated actions, similar or complementary, } \\
\text { taken by companies in interdependent relationships } \\
\text { to achieve mutual or unique results, with } \\
\text { reciprocity expected over time. }\end{array}$ \\
\hline
\end{tabular}

Source: Gupta \& Sahu (2012, pp. 61-63).

\section{Trust}

"Trust has been studied for 30 years in several disciplines and continues to attract the interest of researchers in business-to-business (B2B) marketing" (Akrout, H., Diallo, MF, Akrout, W., \& Chandon, J. L., 2016, p.269). In relationship marketing, trust has been recognized as an important concept (Lagrosen, S. \& Lagrosen, Y. 2012). For Morgan \& Hunt (1994), trust is synonymous with integrity and trustworthiness. These authors consider trust as existing when one party has trust in the reliability and integrity of the other exchange partner (Morgan \& Hunt, 1994). "Trust is the basic mechanism used to build and maintain a relationship and promote long-term orientation in marketing relationships" (Li et al., 2007, p.33).

Trust "becomes even more important for the relationship and for the purposes of developing loyalty when the perceived risk is more pronounced" (Lages et al., 2008, p 688). Trust is used as a basis for strengthening the commitment relationship in organizational sciences (Cambra-Fierro \& Polo-Redondo, 2011).

According to Abosag, Tynan \& Lewis (2006), trust is based on emotion. The authors believe that trust, which one party puts on the other, is based on the feelings and emotions generated by affection, empathy, similarity and concern with the other party, which is demonstrated in their interaction (Abosag et al., 2006).

Trust contributes to reducing the risk of opportunistic behavior in a long-term relationship and therefore contributes positively to long-term customer orientation. In addition, trust increases the buyer's trust that short-term injustices will be resolved and reduce transaction costs in an exchange relationship (Ruiz-Molina \& Gil-Saura, 2012).

\section{Commitment}

There are several authors who explore the importance of commitment. Commitment has been pointed out as an important component of close relationships in B2B (business to business) marketing (Chang, et al., 2012). 
Schmiedel et al. (2013) refer to commitment as the desire and the will to contribute to the achievement of the objectives of the process. According to Morgan \& Hunt (1994), commitment relationship exists only when there is a persevering desire to maintain a relationship which is considered important. According to Berghall (2003), the concept of compromise in commercial relationships refers to a phenomenon in which one side of social interaction limits its behavioral alternatives due to the presence of a long-term orientation.

Trust and commitment are fundamental elements for the success of the relationship marketing strategy (Siguaw, Simpson \& Baker, 1998). Trust decreases perceived risk and vulnerability in a relationship, which leads to a greater commitment to the relationship (Ganesan, 1994). Inter-company relations are guided by relational factors such as commitment standards, which are based on trust (Achrol, 1991; Cambra-Fierro \& PoloRedondo, 2011; Riel et al., 2011).

\section{Cooperation}

Many researchers consider cooperation as a central element in relational exchanges and use this construct to evaluate the quality of a company's relationship (Leonidou et al., 2006, Palmatier et al., 2007). In relations between exporters and distributors, cooperation is essential because it helps companies cope with the complexity and multiplicity of distribution tasks across borders. Several authors propose the following definitions for the construct cooperation.

Schmiedel et al. (2013) identify cooperation as transparency among stakeholders, interoperability and orientation towards constructiveness in communication. Leonidou et al. (2002, p.106) define cooperation as a process, such as "the level of joint effort, team spirit and collaboration between the parties involved in the employment relationship."

Obadia (2008) defines cooperation as a bilateral norm. Cooperation as a relational norm refers to the expectations of parties who must work together to achieve success and solve problems. That is, cooperation is seen as a relational connector that describes how the parties should interact and reflects behavioral expectations in relationship management (Obadia, 2008).

For Anderson \& Narus (1990), the term cooperation comes from the Latin that means "together", operari, "to work", related to situations in which the parties work together to reach mutual objectives. Cooperation has been defined as "similar or complementary coordinated actions taken by companies in interdependent relationships to achieve mutual or unique results with expected reciprocity over time" (Anderson \& Narus, 1990, p. 45).

According to several authors, "cooperation is seen as a central element in exchanges, a sharing, a relational connector that represents a joint effort, working together, teamwork and collaboration, coordination between partners to achieve mutual goals, solve problems and overcome adversities. However, in the case of adversity, cooperation only works if 
there is a prior social relationship. In an international context, cooperation constitutes a mechanism that assists distributors in the performance of their role "(Alves, 2014, p.48).

\section{Culture}

"The word culture is an understanding of a set of equally disordered and extensive material and symbolic concepts ... that give shape and orientation to behavior (and in such a way) that culture is found in the world, in patterns of ideas, practices, institutions, products and artefacts "(Markus \& Kitayama, 2010, p.442). Culture guides people's behavior and, as such, mandatorily has an impact on all aspects of management (Tsoukatos, 2007).

It can be said that the more managers know about culture, the better they will be in the carrying out of their functions, especially when culture has several idiosyncrasies, as is the case of Angolan one (Alves, 2014). In international trade relations, it is crucial to understand culture, since cultural differences often lead to misunderstandings; for example, some cultures perceive certain simple gestures as positive, such as thumbs upward, in American and European cultures, is considered a gesture of approval, while others see it as negative (Islamic and Asian cultures consider the same gesture offensive) (Knapp \& Hall, 2009). Although there are several definitions of the concept of culture, the study by Schmiedel et al. (2013) understands that the concept of culture is mainly defined through invisible values, which are manifested in visible actions and structures, such as ceremonies, customs, technology, products, organizational charts, etc.

\section{Study design}

Regarding the "design of the study", this research englobes a qualitative methodology, namely through interviews. One of the advantages of in-depth interviews is that they allow interviewees to speak freely and the interviewer is free to explore themes without interruption (Robson, 2002).

Interviews to the managers/CEOs of the Portuguese exporting companies and to the employees in charge of exporting activities were performed, as well as to their corresponding Angolan distributors, to obtain answers to the research questions. A total of 15 valid interviews were carried out. The interviews conducted for this research had a duration ranging from about forty-five minutes to one hundred and fifty minutes. When they were authorized to be recorded, they were fully transcribed, making up approximately 200 pages of transcriptions.

The data collected were treated according to a qualitative content analysis (Bardin, 2011).

In short, the data collected are treated according to a qualitative content analysis. This research used a qualitative methodology, an inductive method, the paradigm is constructivist and there is a triangulation of sources. 


\subsection{Sampling}

The sample of exporting companies is constituted of five Portuguese companies, namely: (Petróleos de Portugal-Petrogal. SA (Galp Energia, SGPS, SA - |GE|) e Unicer Bebidas- União Cervejeira, SA - |Unicer|, Efacec Energia, SA ((Grupo EFACEC) |Efacec PT|), Martifer - Construções Metalomecânicas, SA - |Martifer PT| e Acail Indústria e Comércio de Ferro e Aços, SA - |Acail PT|.

The sample of Angolan distributors is constituted of five companies, distributors of Portuguese companies: Mota \& Tavares, Lda - $|\mathrm{M} \& \mathrm{~T}|$ and Importangola SA |Importangola|, Efacec Angola, Lda - |Efacec AG|, Martifer - Construções Metalomecânicas Angola, SA - |Martifer AG| and Acail Angola SA - |Acail AG|.

The criteria for the selection of the case studies were in the case of exporting companies: to be successful Portuguese companies in exporting to the Angolan market and export to the Angolan market through an Angolan distributor. In the case of Angolan companies, in the other five case studies, they had to be distributors of Portuguese companies found in Angola.

The geographical context of this study includes Portugal and Angola. Given the nature of this (intercultural) study, the specific nature of these markets is taken into account.

\section{Study results}

Various definitions of culture consider language as one of its constituent elements. Given that language is one of the key elements culture was the object of analysis of this investigation. Of the five case studies of Portuguese exporting companies, we found testimonies from $|\mathrm{GE}|$, |Martifer PT | and |Efacec PT | in how the same language is central to the realization of commercial relations between Portugal and Angola, given that it facilitates cultural affinity as stated by the $|\mathrm{GE}|$, even creating a competitive advantage for Portuguese companies, as emphasized by $\mid$ Efacec PT $\mid$.

Regarding Angolan distributors, in all case studies, (|Efacec AG|, |Martifer AG|, |M \& $\mathrm{T}$, |Importangola| and |Acail Angola|) consider the same language an important factor, |Importangola | explicitly expresses that "it is an advantage, we speak the same language" and also that "it is also the ideas that are expressed by the phrases whose translation is not language. There is a complete advantage in negotiating with the Portuguese ... ".

Thus, in the light of the case studies analyzed in this investigation, the fact that Portugal and Angola share the same language is considered an advantage for Portuguese companies when they intend to establish trade relations with Angola. According to the testimony of |Martifer AG| it is clear that "feeling the language on the other side (Portugal) ... increasingly feeling more trust"; we can thus deduce that the common language in Angola and Portugal contributes to generating trust, bearing in mind that according to several authors, the presence of trust and commitment are elements in the quality of the relationships (Garbarino \& Johnson, 1999, Ulaga \& Eggert, 2006). 
According to Ghemawat (2001), above mentioned, the attribute that has the most impact on international trade is the colony-colonizer relationship. According to the data collected for the Portuguese exporting companies in this area, |Martifer PT|, |Acail PT|, |Unicer| consider the colony-colonizer attribute to be relevant, and |Martifer PT| states that "it is an advantage for us as a Portuguese company". However, |Unicer| addresses the danger of being perceived as neocolonial and |Efacec AG| goes so far as to say that sometimes the imputation of colonizers is used to treat and cover the current situation in Angola. Nevertheless, on the side of the Angolan distributors, |Martifer AG|, |Acail AG|, $|\mathrm{M} \& \mathrm{~T}|$ and $\mid$ Efacec $\mathrm{AG} \mid$ explicitly consider that the relationship of colony and colonizer is important in the commercial relations between these two countries.|Martifer AG| even indicates that "we already have a relationship of many years ... in one way or another we feel more trust"; we can thus deduce that the colony-colonizer relationship contributes to generate more trust, which is, according to several authors, besides commitment, an element of the quality of the relationship.

We can deduce that common habits and customs (Jain, 1993) result from the period of colonization. According to $|\mathrm{M} \& \mathrm{~T}|$ there were 500 years, " family of 500 years was created, which is almost impossible to separate"; this has the direct consequence, in economic terms, of the consumption of Portuguese products, as shown by the testimonies of the various interviewees, and, in emotional terms, the creation and/or maintenance of greater empathy between the Portuguese and Angolans for sharing something over the years. As we can see from the testimony of $\mid$ Efacec PT| "Portuguese products, I do not know if still out of admiration, are products that have a brand which is affirmed in Angola ... for example Super Bock is the beer that most drink in Angola." It should also be noted that according to |Importangola|, the "brand imported from Portugal has a lot of power", therefore, it also has much more economic value.

It can therefore be concluded, from the analysis of the case study data of the Portuguese exporting companies, |Efacec PT|, |Unicer|, |Acail PT |, |Martifer PT|, that there is a preference for Portuguese products and that these are associated with quality. On the side of the Angolan distributors, |Importangola|, |Efacec AG|, |Acail AG|, |M \& T|, share the same opinion, as we can see from their testimonies. It should be noted that, in addition to the reason given above, $|\mathrm{Efacec} \mathrm{PT}|$ indicates that "Portuguese brands, the result of the work that some have done for many years, have a certain ease because there is a whole image of quality associated to the Portuguese in Angola." Thus, we can conclude that, and citing a statement by |Efacec PT|, "any Angolan distributor is more likely to promote a Portuguese brand than a French brand or a Chinese brand."

|Martifer PT| refers that the Portuguese's capacity for adaptation is greater due to past reality (colonization period). The Portuguese exporting companies that claim to understand the Angolan culture are |Unicer|, |Efacec PT|, |Martifer PT| and |Acail PT|. In light of what Labahn \& Harich (1997, p. 31) claim, national cultural business sensitivity is defined as understanding a company and adapting to the partner's national business practices as perceived by the partner. As we can see from the testimonies of the Angolan distributors, the adaptability of the Portuguese, or, in other words, their sensitivity to the 
Angolan culture, is the reason for the realization of business given the cultural empathy defined by Philips et al. (1994) (cited by Swift, 1999), such as the ability of one seller to position himself as a buyer from another culture. This is evidenced by the testimony of |Importangola|, "with Unicer, it was almost an empathic question."

There is an extremely relevant feature in Angolan culture that should be taken into account when conducting business with Angola, since its lack of consideration may mean, in the light of the testimonies obtained from Portuguese exporting companies |Unicer| and |Acail PT $\mid$ ) and of the Angolan distributors: (|Efacec AG| and |Acail AG|) the nonrealization of business. In other words, according to $\mid$ Efacec AG| "nothing is done in Angola without sparkly." The existence of corruption is one of the characteristic features of societies in which exclusionism prevails (Minkov, 2011).

Trust is composed of honesty (Anderson \& Narus, 1990; Doney \& Cannon, 1997; Dwyer \& Oh, 1987), benevolence (Geyskens et al., 1998; Boersma et al., 2003; Doney \& Cannon, 1997) competence (Helfert et al., 2001; Walter et al., 2003; Boersma et al., 2003) and perceived credibility (Doney \& Cannon, 1997; Boersma et al., 2003).

Honesty means keeping the word reliable and sincere. Benevolence presupposes that one is genuinely committed to one's interests. Competence refers to competence in benefit of the relationship and perceived credibility means one's word, i.e. the partner's perceived statement that they are reliable. As we can see from the statements of all the Portuguese exporting companies present in this investigation, (|Acail PT|, |Martifer PT|, |Unicer|, |GE| and $\mid$ Efacec PT $\mid$ ), these are key to the realization of a business with Angola. For the Angolan distributors |Importangola|, $|\mathrm{M} \& \mathrm{~T}|$, |Acail AG| and |Martifer AG| the fact that the Portuguese have a behavior, based on the above mentioned characteristics, is decisive when buying Portuguese. In other words, in summary and citing $|\mathrm{M} \& \mathrm{~T}|$, "one of the principles is honesty ... because of this, Angola prefers to work with the Portuguese than with any other, this is known" and, citing the |Acail AG|, "They have more trust in Portuguese companies."

Commitment includes behavioral commitment (Brown et al., 1995; Morgan et al., 1994), commitment of continuity (Kim \& Frazier, 1996; Skarmeas et al., 2002), Behavioral compromise (Skarmeas et al., 2002), Commitment of collaboration (Selnes \& Sallis, 2003), Commitment to credibility (Gundlach et al., 1995, Gilliland \& Bello, 2002).

In this context, the authors' the affirmations of Portuguese exporting companies |Acail PT|, |Unicer|, |GE|, and |Efacec PT| and the Angolan distributors (|M \& T|, |Importangola|, |Martifer AG| and |Efacec AG|), show that it is essential for the Portuguese and the Angolans to have a commitment for doing business. In other words, quoting $|\mathrm{M} \& \mathrm{~T}|$, "the main basis must be trust and commitment" ... "the most important, on both sides, not just one. If both parties have this behavior, the business goes far ... "

From the analysis of the case studies of the Portuguese exporting companies we find that for all of them, without exception, (|GE|, |Efacec PT|, |Acail PT|, |Unicer|, |Martifer PT|) trust is fundamental for the realization of business between Portugal and Angola; the 
same applies to all Angolan distributors (|M \& T|, |Efacec AG|, |Acail AG|, |Importangola|, |Martifer AG|) present in this investigation.

An example of total mutual trust between the companies involved is the lack of written contracts. As can be seen from the testimonies of $\mid$ Acail PT $\mid$ - "with the distributor? We do not have a contract. ", of |Importangola | - "... I do not have a written page from Unicer." "I do not have a letter saying that I can be a distributor, nor a letter of contract", |Efacec PT| - "we do not have a contract". This allows the reduction of transaction costs in business relationships, since it is not necessary to write everything down (Usumer \& Lee, 2006).

Another example of the presence of trust is found in keeping one's word, being reliable and sincere (Anderson \& Narus, 1990; Dwyer \& Oh, 1987; Doney \& Cannon, 1997) as we can find in the affirmations of |Importangola|- "commitment and total trust in one's word ", from | Acail PT | - "to do everything very seriously ... to be as correct as possible ... do not try to sell one's word, do not deceive.", from | Martifer AG | - "... full trust that it has been fulfilled" and $|\mathrm{M} \& \mathrm{~T}|$ - "(do not sell) cat for hare." This last testimony exemplifies how trust is defined according to Elg (2002), that is, the exchange partner counts on an honest and reliable behavior of his interlocutor to the detriment of short-term gains obtained by opportunistic behavior.

Selling in Angola "without bank guarantees", as stated by |Acail PT|, or "only when I receive can I pay ... in Portugal", as referred by $\mid$ Efacec $A G \mid$ and, as $|M \& T|$ comments, "over the years I have credit," are testimonials that reveal the existence of trust. According to Parkhe (1998), there are three common characteristics to the definitions of trust: trust related to uncertainty about the future, trust implies vulnerability and trust is given to someone whose behavior is not under control. We can say that the granting of credit means that you trust the other part, since you are not sure if you will receive the money.

Boersma et al. (2003) refer to three bases of trust, namely trust based on promises, trust based on competence, and trust based on benevolence. The dimension of trust called benevolence is intended to assess whether the client views the exporter as a friend and believes that he is on his side (Siguaw et al., 1998). Such are the cases portrayed by |Importangola|, - "we can see a relationship of close friends, between distributors and between administration" - and by $|\mathrm{M} \& \mathrm{~T}|$, "... I have a good relationship, and they are all my friends ".

A competência é outra das dimensões da confiança (Butlle, 1996; Helfert et al., 2001; Walter et al., 2003; Boersma et al., 2003), evidenciada na "capacidade de distribuir produtos com sucesso", como refere a |Unicer|, para "entregar no prazo" e com a "qualidade de serviço", como indica a |Martifer AG|. Podemos assim depreender que tanto os exportadores portugueses como os distribuidores angolanos consideram que a competência é fulcral na concretização de bons negócios.

Competence is another dimension of trust (Butler, 1996; Helfert et al., 2001; Walter et al., 2003; Boersma et al., 2003), as evidenced by the ability to distribute products successfully, as mentioned by |Unicer|, to "deliver on time" and with "quality of service", 
as indicated by |Martifer AG|. We can thus understand that both Portuguese exporters and Angolan distributors consider that competence is central to the achievement of good business.

Perceived credibility corresponds to one of the dimensions of trust (Doney \& Cannon, 1997; Boersma et al., 2003); when a |Unicer| says "have the capacity", or, "demonstrate ability", it is implied that the other party, the distributor, fulfills obligations, based on the size of the trust called "credibility".

Reputation is part of the calculation of trust (Doney \& Cannon, 1997) being referred by |Unicer| as important. In other words, for |Unicer|, the Angolan distributor must: (to build a reputation) "demonstrate a lasting presence in the market and be able to vouch for its reputation the medium/long-term commitment to the market." It is also clear from the previous testimony that trust leads to commitment, in this specific international context, as Morgan \& Hunt (1994) refer to and is explicit in the proposed model.

As can be seen from the analysis of the case studies of Portuguese exporting companies, commitment is considered to be central to $|\mathrm{GE}|$, |Efacec PT|, |Acail PT| and to |Unicer| in the realization of business between Portugal and Angola. Also, the Angolan distributors $|\mathrm{M} \& \mathrm{~T}|$, |Importangola|, |Martifer AG| and |Efacec AG| - consider commitment important in conducting business between Portugal and Angola.

According to Gilliland \& Bello (2002) commitment of attitude is composed of commitment of calculation and commitment of loyalty. In order to maintain a relationship, affective commitment is more effective than the calculation commitment (Sanzo et al., 2003) as we can see from $|\mathrm{M} \& \mathrm{~T}|$ and $|\mathrm{GE}|$, in this investigation.

The testimony of |Importangola| of "continuing to work with them" shows the presence of a commitment to continuity, that is, the desire to continue the relationship (Skarmeas et al., 2002).

When $|\mathrm{M} \& \mathrm{~T}|$ refers "He phoned me to say that I was worried about paying for things ... if I could afford it. I have sent, I have transferred the money ... "it shows the existence of a behavioral commitment, that is, the fact that the distributor provides assistance to the international supplier in times of need (Skarmeas et al., 2002).

When |Importangola| mentions "continuing to work with them (Unicer), market consolidation" and other testimonies of other case studies when referring to reliable deliveries, evidence the commitment to collaboration as defined by Selnes \& Sallis (2003).

Credibility commitment corresponds to the investments and behavioral actions that maintain a part linked to an organization (Gilliland \& Bello, 2002; Gundlach et al., 1995); this can be seen from the testimony of |Efacec AG|, "should link (the Portuguese company) ... to do continuous monitoring, should provide technical support and continuous monitoring." 
In sum, both trust and commitment have an impact on the achievement of business between Portuguese exporting companies and Angolan distributors.

As already mentioned, from the analysis of the case studies of Portuguese exporting companies, we find that for all of them, without exception, trust is fundamental for the accomplishment of business between Portugal and Angola; the same applies to all Angolan distributors present in this investigation. As regards commitment, as was previously mentioned, for Portuguese exporting companies this is considered to be central to $|\mathrm{GE}|$, |Efacec PT|, |Acail PT| and for |Unicer| in the realization of business between Portugal and Angola. Also, the Angolan distributors - |M \& T|, |Importangola|, |Martifer $\mathrm{AG} \mid$, |Efacec AG| - mention commitment as being important in conducting business between Portugal and Angola. The quality of the relationship present in the case studies of this investigation is thus evident.

According to Leonidou et al. (2002), cooperation is a process in which the level of effort is joint, there is team spirit and there is collaboration between the parties involved in the working relationship and Anderson \& Narus (1990) relates cooperation with situations in which the parties work together in order to achieve mutual goals. As we can see from the testimonies of |Efacec PT | - "It is a supportive positioning, it is a positioning to do the rearguard because Efacec Angola, in itself, would not survive. It has all the support ... ", and |Efacec AG| - "it is a continuous relationship with continuous help ...", from |Martifer PT| - "Martifer Portugal's relationship with Angola has been a great partnership relationship"; and "|Martifer AG | -" business alignment and common interests, with the goal of creating value for all parties involved. "; of |Acail PT| - "It was always this: mutual aid, always collaboration ..."; from |Importangola | - "we worked well with Unicer ... a partnership-type relationship, more than a commercial relationship"; of $|\mathrm{GE}|$ - "perfectly normal and healthy relationships with structured cooperation policies"; and $|\mathrm{M} \& \mathrm{~T}|$ - "... working together".

According to Obadia (2008), cooperation is a relational norm that refers to the expectations of the parties that must work together to achieve success and solve problems, and for Heide \& John (1992), the relational norms of exchange are based on the expectations of reciprocity of interests, essentially prescribing cordial behavior and are intended to increase the well-being of the relationship as a whole.

This can be identified in the testimonies of the case studies, such as M \& T | - "I continue to work with them in the future, work together. They also provide their share ... ", and |Efacec PT | - "Our expectations are that our size will continue to grow. And it will continue to grow based on two pillars: a pillar that is the pillar of the guard ... "and |Efacec AG $\mid$ - "... the relationship has to be egalitarian, it cannot be a patriarchal relationship, to give orders from (Portugal) to (Angola), not." 


\section{Conclusions and implications}

In general terms, the results show that culture, trust, commitment and cooperation significantly affect the context of internationalization of business. Confirming some theoretical proposals, it becomes clear that these constructs affect the commercial relations between Portuguese exporting companies and Angolan distributors.

The understanding of local culture and its idiosyncrasies, the indispensability of realizing that, although there are common cultural traits, others are quite different, the need for a cultural empathy, an "angolanization" which responds to the Angolan aspirations /yearnings "angolanity" of the local partners, are aspects that are not of the least importance.

The results of this investigation reveal that the adaptation to the market - which many might a priori mistakenly consider a low-cost market - is crucial, as well as the imperative need to maintain a lasting local presence, showing commitment to the market. Building partnerships with local organizations is also highly commendable, because of the ease of movement knowledge in the market, that they provide. The participation of Angolans in key sectors is also important. However, the selection of reliable distributors may not be an easy task, since opportunistic situations have been detected. It is also worth noting that the need to adapt to the market and the avoidance of an ethnocentric attitude on the part of Portuguese exporters - "what is true here is not true there" - despite cultural similarity, requires a continuous study of market developments.

The concern to provide quality offers at suitable prices is consensual. The ability and speed of response to market demands - remember that it is a country that has an urgent need to rebuild, with needs of all kinds - which presupposes the existence of efficient logistics, technical and marketing capacity, after-sales service and relationship management, and understanding of the local way of doing business-conditioned by different ethical standards-are also important.

One of the limitations that may be pointed out in this investigation is that it is based on a qualitative analysis, that is, on the interpretation of a person; as such, generalizations have to be taken care of.

Another limitation that can be pointed out is the fact that this study is multisectorial, since it applies more to the general relationship of companies, without focusing on any particular sector, removing homogeneity.

The limited time to complete this research can be considered a barrier that conditions the researcher's options, such as the impossibility of having more interviews. Data collection through in-depth interviews is subject to the scarce availability of respondents, which has lengthened this process over time. However, if we take as reference several international publications, it can be seen that they are based on a smaller number of case studies than those included in this research. 
For a more complete understanding of the object of study of this investigation the same study using a design/data in longitudinal terms is to be done.

With regard to recommendations for future investigations, it is suggested to replicate this same investigation with regard to Portuguese exporting companies, but to other markets, such as Brazil or Mozambique. As these countries, also Portuguese ex-colonies, having Portuguese as the official language, may evaluate the confirmation or rejection of the contributions of this study and the underlying causes.

Another suggestion may be to carry out this research based on Portuguese exporting companies that have failed in the Angolan market, instead of successful Portuguese exporting companies, allowing subsequent comparative analysis, thus detecting similarities and/or differences.

The possibility of investigating the effect of other relational variables is also suggested.

One way forward for future research may be to include other fiscal, legal, logistical and financial wraparounds in the model, and to study their joint and multilateral effects, in addition to cultural surroundings, on business relationships. This suggestion results from the verification of the impact that they have on the realization of business in Angola, being certain that many of the occurrences in these surroundings have a cultural root. It may also be interesting to study the feedback effect of cooperation on trust.

\section{References}

Abosag, I., Tynan, C., \& Lewis, C. (2006). The commitment-trust theory: The British and Saudi Arabian cross-national perspectives [Conference presentation]. $22^{\text {nd }}$ IMP Conference, Milan, Italy.

Achrol, R. S. (1991). Evolution of the marketing organization: new forms for turbulent environments. Journal of Marketing, 55(4), 77-93. https://doi.org/10.1177/002224299105500406

Agência para o Investimento e Comércio Externo de Portugal. (2011). http://www.portugalglobal.pt.

Alareeni, B., \& Branson, J. (2011). The relative performance of auditors' going-concern opinions and statistical failure prediction models in Jordan. Accountancy \& Bedrijfskunde, 8, 23-35.

Alqallaf, H., \& Alareeni, B. (2018). Evolving of selected integrated reporting capitals among listed Bahraini banks. International Journal of Business Ethics and Governance, 1(1), 15-36. https://doi.org/10.51325/ijbeg.v1i1.10

Alves, G. (2014). O impacto da cultura e qualidade do relacionamento na cooperação entre as empresas exportadoras e distribuidores locais [Unpublished doctoral dissertation]. Universidade do Minho, Portugal.

Anderson, E., \& Coughlan, A. T. (1987). International market entry and expansion via independent or integrated channels of distribution. Journal of Marketing, 51(1), 7182. https://doi.org/10.1177/002224298705100106

Anderson, J. C., \& Narus, J. A. (1990). A model of distributor firm and manufacturer firm working partnerships. Journal of Marketing, 54(1), 42-58. https://doi.org/10.1177/002224299005400103

Bardin, L. (2011). Análise de Conteúdo (4ª edição). Lisboa: Edições 70 Lda. 
Berghäll, S. (2003). Perceptions of dyadic business relationships: In search of the social psychological basis of interpersonal relationship perceptions in socio-economic exchange relationships. Marketing Theory, 3(1), 59-77. https://doi.org/10.1177/1470593103003001004

Boersma, M. F., Buckley, P.J., \& Ghauri, P.N. (2003). Trust in international joint venture relationships. Journal of Business Research, 56(12), 1031-42. https://doi.org/10.1016/S0148-2963(01)00315-0

Brito, C., \& Lencastre, P. (2014). Novos horizontes do Marketing. Lisboa: Dom Quixote.

Buttle, F. (Ed.) (1996). Relationship Marketing: Theory and Practice. SAGE Publications Ltd. https://doi.org/10.4135/9781446252062

Cambra-Fierro, J. J., \& Polo-Redondo, Y. (2011). Postsatisfaction factors affecting the long-term orientation of supply relationships. Journal of Business \& Industrial Marketing, 26(6), 395-406. https://doi.org/10.1108/08858621111156395

Chang, S. H., Wang, K. Y., Chih, W. H., \& Tsai, W. H. (2012). Building customer commitment in business-to-business markets. Industrial Marketing Management, 41(6), 940-950. https://doi.org/10.1016/j.indmarman.2011.11.026

Doney, P. M., \& Cannon, J. P. (1997). An examination of the nature of trust in buyerseller relationships. Journal of Marketing, 61(2), 35-51. https://doi.org/10.1177/002224299706100203

Douglas, S.P., \& Craig, S. (1995). Global marketing strategy. New York: McGraw Hill.

Dwyer, F. R., Schurr, P. H., \& Oh, S. (1987). Developing buyer-seller relationships. Journal of Marketing, 51(2), 11-27. https://doi.org/10.1177/002224298705100202

Elg, U. (2002). Inter-firm market orientation: Its significance and antecedents in distribution networks. Journal of Marketing Management, 18(7-8), 633-655. https://doi.org/10.1362/0267257022780697

Ganesan, S. (1994). Determinants of long-term orientation in buyer-seller relationships. Journal of Marketing, 58(2), 1-19. https://doi.org/10.2307/1252265

Garbarino, E., \& Johnson, M. (1999). The different roles of satisfaction, trust, and commitment in customer relationships. Journal of Marketing, 63(2), 70-87.

Geyskens, I., Steenkamp, J. B. E., \& Kumar, N. (1998). Generalizations about trust in marketing channel relationships using meta-analysis. International Journal of Research in Marketing, 15(3), 223-248. https://doi.org/10.1016/S01678116(98)00002-0

Ghemawat, P. (2001). Distance still matters the hard reality of global expansion. Harvard Business Review, 79(8), 137-47.

Gilliland, D. I. \& Bello, D. C. (2002). Two sides to attitudinal commitment: The effect of calculative and loyalty commitment on enforcement mechanisms in distribution channels. Journal of the Academy of Marketing Science, 30(1), 24-43. https://doi.org/10.1177/03079450094306

Griffith, D., Myers, M., \& Harvey, M. (2006). An investigation of national culture's influence on relationship and knowledge resources in interorganizational relationships between Japan and the United States. Journal of International Marketing, 14(3), 1-32. https://doi.org/10.1509/jimk.14.3.1

Gummerus, J., von Koskull, C., \& Kowalkowski, C. (2017). Relationship marketingpast, present and future. Journal of Services Marketing, 31(1), 1-5. https://doi.org/10.1108/JSM-12-2016-0424

Gummesson, E. (2017). From relationship marketing to total relationship marketing and beyond. Journal of Services Marketing, 31(1), 16-19. https://doi.org/10.1108/JSM$\underline{11-2016-0398}$ 
Gundlach, G. T., Achrol, R. S., \& Mentzer, J. T. (1995). The structure of commitment in exchange. Journal of Marketing, 59(1), 78-92. https://doi.org/10.1177/002224299505900107

Gupta, A., \& Sahu, M. (2012). A literature review and classification of relationship marketing research. International Journal of Customer Relationship Marketing and Management, 3(1), 56-81. https://doi.org/10.4018/ijcrmm.2012010104

Ha, J., Karande, K., \& Singhapakdi, A., (2004). Importers' relationships with exporters: Does culture matter? International Marketing Review, 21(4/5), 447-461. https://doi.org/10.1108/02651330410547135

Heide, J. B., \& John, G. (1992). Do norms matter in marketing relationships? Journal of Marketing, 56(2), 32-44. https://doi.org/10.1177/002224299205600203

Helfert, G., Ritter, T., \& Walter, A. (2001). How does market orientation affect business relationships? [Conference presentation]. 17th IMP Conference, Oslo, Norway.

Jain, S. C. (1993). International marketing management (4th ed.). Belmont, California: Wadsworth.

Kim, K., \& Frazier, G.L. (1996). A typology of distribution channel systems: A contextual approach. International Marketing Review, 13(1), 19-32. https://doi.org/10.1108/02651339610111326

Kim, S., Hibbard, J., \& Swain, S. (2011). Commitment in marketing channels: Mitigator or aggravator of the effects of destructive acts? Journal of Retailing, 87(4), 521539. https://doi.org/10.1016/j.jretai.2011.09.006

Knapp, M. L., \& Hall, J. A. (2009). Nonverbal communication in human interaction $\left(7^{\text {th }}\right.$ ed.). Boston: Wadsworth.

LaBahn, D. W., \& Harich K. R. (1997). Sensitivity to national business culture: Effects on U.S. - Mexican channel relationship performance. Journal of International Marketing, 5(4), 29-51. https://doi.org/10.1177/1069031X9700500404

Lages, L., Lancastre, A., \& Lages, C. (2008). The B2B-RELPERF scale and scorecard: Bringing relationship marketing theory into business-to-business practice. Industrial Marketing Management, 37, 686-697. https://doi.org/10.1016/j.indmarman.2007.05.008

Lagrosen, S., \& Lagrosen, Y. (2012). Trust and quality management: Perspectives from marketing \& organisational learning. Total Quality Management \& Business Excellence, 23(1), 13-26. https://doi.org/10.1080/14783363.2011.637794

Leonidou, L. C., Barnes, B. R., \& Talias, M. A. (2006). Exporter-importer relationship quality: The inhibiting role of uncertainty, distance and conflict. Industrial Marketing Management, 35, 576-588. https://doi.org/10.1016/j.indmarman.2005.06.012

Leonidou, L. C., Katisikeas, C. S. \& Hadjimarcou, J. (2002). Building successful export business relationships: A behavioral perspective. Journal of International Marketing, 10(3), 96-115. https://doi.org/10.1509/jimk.10.3.96.19543

Li, D., Browne, G. J. \& Wetherbe, J. C. (2007). Online consumers' switching behavior: a buyer-seller relationship perspective. Journal of Electronic Commerce in Organizations, 5(1), 30-42. https://doi.org/10.4018/jeco.2007010102

Markus, H. R., \& Kitayama, S. (2010). Cultures and selves. Perspectives on Psychological Science, 5(4), 420-430. https://doi.org/10.1177/1745691610375557

Minkov, M. (2011). Cultural differences in a globalizing world. Bingley, UK: Emerald Group Publishing Limited.

Miocevic, D. (2016). The antecedents of relational capital in key exporter-importer relationships: An institutional perspective. International Marketing Review, 33(2), 196-218. https://doi.org/10.1108/IMR-02-2015-0022 
Miquel-Romero, J. M., Caplliure-Giner, E. M. \& Adame- Sánchez, C. (2014). Relationship marketing management: Its importance in private label extension. Journal of Business Research, 67, 667-672. https://doi.org/10.1016/j.jbusres.2013.11.025

Morgan, R., \& Hunt, S. (1994). The commitment-trust theory of relationship marketing. Journal of Marketing, 58(3), 20-38. https://doi.org/10.1177/002224299405800302

Navarro-García, A., Arenas- Gaitán, J., \& Rondán- Cataluña, F. J. (2014). External environment and the moderating role of export market orientation. Journal of Business Research, 67, 740-745. https://doi.org/10.1016/j.jbusres.2013.11.037

Obadia, C. (2008). Cross-border inter-firm cooperation: The influence of the performance context. International Marketing Review, 25(6), 634-650. https://doi.org/10.1108/02651330810915565

Palmatier, R. W., Dant, R. P. \& Grewal, D. (2007). A comparative longitudinal analysis of theoretical perspectives of interorganizational relationship performance. Journal of Marketing, 71(4), 172-194. https://doi.org/10.1509/jmkg.71.4.172

Parkhe, A. (1998). Building trust in international alliances. Journal of World Business, 33(4), 417-437. https://doi.org/10.1016/S1090-9516(99)80083-2

Raciti, M. M., \& Dagger, T. S. (2017). Relationship marketing: looking backwards towards the future. Journal of Services Marketing, 31(1), 1-8. https://doi.org/10.1108/JSM-11-2016-0380

Riel, A. C. R., Liljander, V., Semeijn, J., \& Polsa, P. (2011). EU deregulation and dealersupplier relations in automotive distribution. Journal of Business \& Industrial Marketing, 26 (2), 115-131. https://doi.org/10.1108/08858621111112294

Robson, C. (2002). Real world research: A resource for social scientists and practitionerresearchers. Oxford, England: Blackwell.

Ruiz-Molin, M-E., \& Gil-Saura, I. (2012). Relationship and market conditions: Outcomes in marketing channels. Journal of Business-to-Business Marketing, 19, 289-308. https://doi.org/10.1080/1051712X.2012.647796

Saleh, M. A., Ali, M. Y. \& Andaleeb, S. S. (2014). Explaining industrial importers' commitment from an emerging market perspective: theoretical and managerial insights, Journal of Business \& Industrial Marketing, 29(1), 45-62. https://doi.org/10.1108/JBIM-09-2011-0116

Sanzo, M.J., Santos, M.L. Vázquez, R, \& Álvarez. L.I (2003). The role of market orientation in business dyadic relationships: Testing an integrator model, Journal of $\begin{array}{lll}\text { Marketing } \quad \text { Management, } & \text { 73-107. }\end{array}$ https://doi.org/10.1362/026725703763771971

Schmiedel, T., Brocke, J. \& Recker, J., (2013). Which culture values matter to business process management? Results from a global Delphi study. Business Process Management $\quad$ Journal, 292-317. https://doi.org/10.1108/14637151311308321

Selnes, F., \& Sallis, J. (2003). Promoting relationship learning. Journal of Marketing, 67(3), 80-95. https://doi.org/10.1509/jmkg.67.3.80.18656

Siguaw, J. A., Simpson, P. M., \& Baker, T.L. (1998). Effects of supplier market orientation on distributor market orientation and the channel relationship: The distributor perspective. Journal of Marketing, 62(3), 99-111. https://doi.org/10.2307/1251746

Skarmeas, D., Katsikeas, C. S., \& Schlegelmilch, B. B. (2002). Drivers of commitment and its impact on performance in cross-cultural buyer-seller relationships: The importer's perspective. Journal of International Business Studies, 33(4), 757-83. https://doi.org/10.1057/palgrave.jibs.8491043 
Swift, J. S. (1999). Cultural closeness as a facet of cultural affinity a contribution to the theory of psychic distance. International Marketing Review, 16(3), 182-201. https://doi.org/10.1108/02651339910274684

Tsoukatos, E., \& Rand, G.K. (2007). Cultural influences on service quality and customer satisfaction: Evidence from Greek insurance. Managing Service Quality, 17(4), 467485. https://doi.org/10.1108/09604520710760571

Ulaga, T., \& Eggert, A. (2006). Value-based differentiation in business relationships: Gaining and sustaining key supplier status. Journal of Marketing, 70(1), 119-136. https://doi.org/10.1509/jmkg.70.1.119.qxd

Usunier, J. C. \& Lee, J. (2005). Marketing across cultures $\left(4^{\text {th }}\right.$ ed.). London: Pearson Education Limited.

Walter, A, Müller, T. A., Helfert, G., \& Ritter, T. (2003). Functions of industrial supplier relationships and their impact on relationship quality. Industrial Marketing Management, 32(2), 159-169. https://doi.org/10.1016/S0019-8501(02)00230-4. https://doi.org/10.1016/S0019-8501(02)00230-4. 